\title{
VERDADES IRREALES. FENOMENOLOGÍA DE LA FICCIÓN Y MODIFICACIÓN DE NEUTRALIDAD
}

\author{
César Moreno-Márquez \\ Universidad de Sevilla
}

Resumen: Desde una perspectiva fenomenológica, recursos como el análisis intencional o lo que en Ideas I (Husserl) se denomina modificación de neutralidad (en la que no nos afecta la cuestión acerca de lo real o lo irreal) resultan imprescindibles para comprender la dinámica de la ficcionalidad y la relevancia de la verosimilitud. A partir de tres casos (Marbot,Jimmy's World y la fotografía Muerte de un miliciano) y de las prácticas del nuevo periodismo y del efecto-extrañamiento (Brecht), se explora en este estudio una de las claves de la necesidad de la experiencia literaria, a saber, que la realidad no puede apropiarse de la verdad, por lo que es perfectamente razonable proponer la validez de verdades irreales.

Palabras clave: Ficción, Realidad, Verdad, Verosimilitud, Modificación de neutralidad, Literatura, Nuevo periodismo, Jimmy's world, Fenomenología, Husserl.

Abstract: Resources such as intentional analysis, as well as what in (Husserl's) Ideas I is named Neutrality-modification (in which the question about what is real or unreal does not affect us) are essential from a phenomenological perspective to understand the dynamics of fictionality and relevance of verisimilitude. Using three cases (Marbot, Jimmy's World and the photograph Loyalist Militiaman at the Moment of Death) and the practices of New Journalism in addition to the alienation-effect (Brecht), this study explores one of the keys to the need of the literary experience, namely: that reality cannot appropriate the truth, so it is perfectly reasonable to suggest the validity of unreal trutbs.

Keywords: Fiction, Reality, Truth, Verisimilitude, Neutrality modification, Literature, New Journalism, Jimmy's world, Phenomenology, Husserl. 
«La literatura no es un simple engaño, es el peligroso poder de ir hacia lo que es por la infinita multiplicidad de lo imaginario. La diferencia entre lo real y lo irreal, el inestimable privilegio de lo real, reside en que hay menos realidad en la realidad por no ser ésta más que la irrealidad negada, apartada por el enérgico trabajo de la negación» ${ }^{1}$.

«Hay que comprender lo que es la novela. Un historiador relata acontecimientos que han tenido lugar. Por el contrario, el crimen de Raskolnikov jamás ha visto la luz del día. La novela no examina la realidad, sino la existencia. Y la existencia no es lo que ya ha ocurrido, la existencia es el campo de las posibilidades humanas. [...] En Kafka, todo esto está claro: el mundo kafkiano no se parece a ninguna realidad conocida, es una posibilidad extrema y no realizada del mundo humano. [...] Territorio de la existencia quiere decir: posibilidad de la existencia. Que esta posibilidad se transforme o no en realidad, es secundario. [...] Si el autor considera una situación histórica como una posibilidad inédita y reveladora del mundo humano, querrá describirla tal cual es. El caso es que la fidelidad a la realidad histórica es algo secundario en relación al valor de la novela. El novelista no es ni un historiador ni un profeta: es un explorador de la existencia» ${ }^{2}$.

\section{PRIMERA PARTE}

\section{Una dialéctica de dominios y ocupaciones}

Tensionada dialécticamente como se encuentra, desde el principio, por su referencia a la percepción de lo real, sea porque para hacerse cargo de lo irreal/ inexistente debiera experimentarse en cierta deuda indirecta de reconocimiento con lo real/existente, o porque buscase transformar o transgredir en grados diversos lo real percibido, en este sentido, la ficción y su reino de lo Inexistente ${ }^{3}$ parece la hermana menor de la percepción de lo que llamamos realidad, y como recién llegada cuando casi todo el espacio parece que estuviera ocupado por lo real, de modo que a la ficción le restaría solamente un "hueco" de inspiración. Así pues, en su proceso de ficcionalización, la ficción siempre sería "segunda"

${ }^{1}$ Blanchot, M. El libro que vendrá. Caracas: Monte Avila Editores, 1992, pp.: 111-112.

${ }^{2}$ Kundera, M. El arte la novela. Barcelona: Tusquets, pp.: 53-54.

3 "Inexistente" en un sentido que no se dejaría reducir a "lo que no existe". Por ejemplo, hay obras de arte, especialmente pictóricas o escultóricas, que "existen" en el mundo que llamamos real -por ejemplo, podría encontrárselas en tal o cual museo-, y que, sin embargo, convocan lo Inexistente, están ahí justo para llevar a cabo esa convocatoria de percepción ensoñadora-conlos-ojos-cerrados-abiertos-de-par-en-par, porque por más que buscásemos fuera de esas mismas obras, no hallaríamos en medio del mundo cotidiano que llamamos real nada parecido a aquello que, digamos, "representan". Por ejemplo, pienso en Cadeau de Man Ray o en Monogram de Robert Rauschenberg. 
con relación a la primariedad de la percepción de lo real. Por su parte, la ficción, siempre renaciente, imposible de acallar ni siquiera porque se le recordase su secundariedad (y aquí no entraremos en la posible múltiple génesis del deseode-ficción), se hace dueña del placer de lo irreal y se venga—o se burlade la percepción de lo real, siempre atosigada por aquello a lo que se debe, recordándole-lo decía Blanchot-que en el fondo a lo que se entrega o busca encumbrar no es sino el ahuecado (incluso angostado) recorte, en cada caso, de una plétora inmensa de posibilidades que aunque la realidad quisiera ignorar, ella, la ficción, puede conocer y con frecuencia no deja que la realidad olvide, recordándole de este modo su precariedad (ipor más que por su poder de selección la realidad haga triunfar como acontecido todo aquello a lo que permite acontecer!). Quizás era esto lo que quería decir André Breton cuando proclamaba: «amada imaginación, lo que más amo en ti es que jamás perdonas» ${ }^{4}$.

Por su parte, amén de subordinada formal-dialécticamente a la percepción de lo real, a la ficción en cuanto tal, en su diferancia, la acosa con extrema frecuencia la atracción no por los contenidos de lo real, a los que usualmente la ficción se complace en desmentir, negar o transformar, sino por la formalidad misma de realidad. Se trata de una venganza sutil por parte de la percepción de lo real. Que la ficción se experimente atraída por la cualidad de lo real no significaría sino que la ficción aspira a ser considerada como $s i^{5}$ fuese realidad, sea porque buscara proponer sus contenidos como-si-fueran-reales, sea porque la ficción estuviera animada por un pathos que comprometiera por completo al sujeto de la ficción. Así pues, creyendo poder vencer a lo real por sus "otros contenidos", sin embargo, la ficción caería seducida por el pathos de la realidad como deseo-de-realidad , devenido más decisivo que sus propios contenidos contingentes. Después de todo (cabe imaginar que así razonaría la percepción de lo real), ¿qué importa que se vaya más allá de esta o aquella manifestación de lo real, si finalmente se desea la fuerza de la realidad misma en el deseo que la desea para apropiarse de su peso y su prestigio? Y aun así-otra vuelta de tuerca - la ficción creería poder herir a la percepción de lo real cuando, incluso reconociendo su deseo-de-realidad, hiciese jugar a éste a su favor para lanzar contra la realidad otros contenidos, siendo que la percepción de lo real se complace en justamente-tales-contenidos-y-no-otros, a

4 Breton, A. "Primer manifiesto del surrealismo" [1924]. En Manifiestos del surrealismo, Barcelona: Labor, 1992, p.: 19.

${ }^{5}$ Fue Vaihinger quien popularizó lo que llamó la "filosofía del Como si", de la que aquí no puedo sino señalar su aportación (cfr. Vaihinger, H. Die Philosophie des Als-Ob. Darmstadt: Scientia Verlag, 1986).

6 Siempre insatisfecho con las meras representaciones y las ficciones en tanto meras ensoñaciones, delirios, etc. Cfr. Moreno, C., "Deseo de realidad. Un fragmento (autobiográfico) de mi Discurso del método". En AA.VV., Que piensen ellos, Madrid: Opera Prima, 2001, pp.: 127-140. Cfr. también Moreno, C. "Dinámica de la intuición. Reflexiones sobre la donación fenomenológica y el fin del conocimiento en Husserl (con una incursión en el caso-Chandos)". En Signo, intencionalidad, verdad. Estudios de Fenomenología (César Moreno y Alicia de Mingo, eds.), Sevilla: Universidad de Sevilla, 2005, pp.: 57-70. 
los que otorga la confianza de brindarle a ella misma su fuerza y contundencia. Deseando la realidad, la ficción amenaza con alterar la percepción de lo real. Alonso Quijano estaba en perfectas condiciones para comprender esa amenaza. ¿Acaso no es "muy importante"—pensaría la actitud natural—, que vea gigantes y no molinos? Es cierto que no todas las ficciones desean la realidad, si se me permite decirlo así. Las más fantásticas (en el sentido de inverosímiles) la rehúyen expresamente. En tal caso, sin embargo, el pathos más afectivo parece seguir operando a favor ya no propiamente de la percepción de lo real, pero sí de una empatía lúdica que compensaría la ausencia de un contenido verosímil, y que habría de quedar preservada aunque hubiese sucumbido toda percepción de realidad y toda verosimilitud. Para Lotman,

«Propiedad importante del comportamiento artístico es el hecho de que el que lo practica realiza simultáneamente, por así decirlo, dos conductas: vive todas las emociones que suscitaría una situación práctica análoga y, al mismo tiempo, es claramente consciente de que no se deben llevar a cabo las acciones relacionadas con esta situación (por ejemplo, prestar ayuda al protagonista). La conducta artística supone la síntesis de lo práctico y de lo convencional.

Examinemos el verso de Pushkin: Me desharé en lágrimas ante la ficción. Se trata de una brillante caracterización de la doble naturaleza del comportamiento artístico. Aparentemente, la conciencia de que nos hallamos ante una ficción debería excluir las lágrimas. $\mathrm{O}$ por el contrario: el sentimiento que suscita las lágrimas nos haría olvidar que nos encontramos ante una ficción. De hecho, ambos tipos—opuestos—de conducta existen de modo simultáneo ahondándose mutuamente» 7 .

En efecto. La ficción puede ser realista (en grados diversos de verosimilitud verdadera o heterocósmica) o fantástica (imposible o casi imposible, utópica, en términos de Baumgarten ${ }^{8}$ ). En este caso, a cambio de inverosimilitud (que aboca al ostracismo o la segregación, o bien a la salvación de lo inverosímil extremo por el arte), la ficción se reafirma en su desafiante hybris contando únicamente con sus contenidos inequívocamente irreales, incluso al borde de lo imposible ${ }^{9}$, y con el principio de la adhesión empática. Y ocurre a veces, alarmantemente,

${ }^{7}$ Lotman, Y. Estructura del texto artístico. Barcelona: Itsmo, 1982, p.: 89. Cfr. Pozuelo Yvancos, J.M. Poética de la ficción. Madrid: Síntesis, 1993. Es interesante que Lotman haya conducido lo lúdico del comportamiento artístico al terreno de las lágrimas, sin duda más cercano al pathos de lo real, que al terreno de la risa. Pienso que como complemento a las lágrimas de Puskin/ Lotman estaría el humor que reivindica Kundera al comienzo de Los testamentos traicionados como expresión de la pura ficción, o de la ficción pura, añorada por la Novela. Vid. el texto de Kundera que se corresponde con nuestra nota 50.

${ }^{8}$ Baumgarten, A. G. Reflexiones filosóficas acerca de la poesía. Madrid: Aguilar, 1964, pp.: 55-56.

${ }^{9}$ Como dice Albaladejo, la ficción literaria se extiende contemporáneamente incluso a lo utópico-imposible (Albaladejo, T. Semántica de la narración: la ficción realista. Madrid: Taurus, 1992, p.: 86. En general, en este estudio se encontrarán numerosas sugerencias respecto al tema que aquí nos ocupa). 
que ni siquiera con esta adhesión, deliberadamente dificultada (como en cierta literatura de vanguardia - pienso en un Kafka, por ejemplo) en el lapso del pacto de suspensión de la incredulidad. En cualquier caso, la adhesión fría o la empatía lúdica son importantes porque a veces cobran más relevancia que la decisión intelectiva acerca de lo real y lo irreal, que pasa pactada y transitoriamente a ser secundaria. Entonces, el valor de la presencia (relato, pintura, obra de arte, etc.) no depende de si lo que muestra es real o no, sino de las potencialidades de la conciencia suscitadas por la verdad irreal que esa presencia convoca.

\section{VERDADES IRREALES Y FICCIONES INFILTRADAS. TRES CASOS}

\section{II.1. Ficciones infiltradas contaminantes}

No se insistirá lo suficiente en hasta qué punto lo que llamamos lisa y llanamente realidad, al mismo tiempo que se nos da como realidad-sin que deba escamotearse un ápice esta donación fenomenológica en cuanto tal, discernible de otros tipos de donación-está completa y desapercibidamente enredada en muchas ocasiones con creencias, ideas, discursos, experiencias, etc. que no pertenecen propiamente a eso que tan contundente y positivistamente llamamos "realidad". Aparte de que estos enredos brindarían un material muy valioso a descripciones densas ${ }^{10}$ en un horizonte básicamente hermenéutico, también es cierto que, más en un estilo deconstructivo, contribuirían a desdibujar la distinción tajante entre ficción y realidad, en la medida en que las ficciones pudieran deslizarse subrepticiamente hacia y en medio de lo real, que se dejaría impregnar por ellas- por más que antes haya sido en lo que llamamos realidad o en sus entornos donde haya podido surgir eso que luego vuelve a la percepción de lo "real" bajo la modalidad de ficciones infiltradas, a las que Javier Marías llama bastardas.

Todos conocemos sobradamente la más importante de las ficciones infiltradas contaminantes. Sin duda, las que se introducen en el mundo de Alonso Quijano trasformando su circunmundo y a él mismo en Don Quijote de la Mancha. También son muy conocidas-entre otros muchos ejemploslas que gozaba o padecía Madame Bovary. Las ficciones se fugan de su reserva y pasan viralmente a inmiscuirse en la percepción de lo real, y no sólo en sujetos trastornados psíquicamente (Don Quijote) o sólo por un medio, sino, hoy por hoy, multimedialmente. Cuando salen de su redil, sin nada que las contenga o acote, las ficciones deben buscar portadores, sujetos o mundos potenciales en los que alojarse... o a los que parasitar el principio de realidad.

Dice Javier Marías que la Navidad ha abandonado el terreno de la realidad $\mathrm{y}$ ha pasado al de la ficción bajo el influjo ficcional de, por ejemplo, Cuento de Navidad, de Dickens, o de ¡Qué bello es vivir!, el film de Frank Capra. Aunque

${ }^{10}$ Geertz, C. La interpretación de las culturas. Barcelona: Gedisa, 1989, pp.: 19-40. 
antes estas ficciones tenían vigencia, aun así, el individuo podía establecer cierta distancia entre los productos ficcionales y la realidad, no estando ésta tan "contaminada" por la ficción. Dice Marías que:

«vivimos en un mundo tan saturado de ficciones que nadie puede sustraerse a ellas o a la huella que dejan, cada vez más marcada, en el espíritu y el carácter de los contemporáneos. La ficción, antiguamente, se alimentaba en buena medida de la realidad o la tenía como referencia excepto en aquellas obras que eran clara y deliberadamente fantásticas. Hoy sucede al revés: no es sólo que la realidad imite al arte, como dijo Oscar Wilde [...], sino que el arte condiciona y domina nuestra realidad [...] rara es hoy la situación en que alguien puede encontrarse a lo largo de su vida, raros son los sentimientos o las dudas o las obsesiones o los odios o las pasiones que pueda experimentar-rara es la vivencia—, que no hayan sido ya tocados o usurpados por alguna ficción, a la cual ese alguien se verá remitido inmediatamente, teniendo la sensación de que todo lo vive por mímesis o, por decirlo de manera más cruda, por segunda vez.

Quien no desee estar en contacto con la ficción no podrá escapar a ella. [...] No estoy seguro de que esto sea bueno ni malo. Lo juzgarán lamentable quienes vean en ello una pérdida de autenticidad y espontaneidad, y les parecerá estupendo a quienes crean que tales cosas no son necesariamente virtudes, y que en un mundo privado de normas religiosas y hasta cierto punto morales es un consuelo que al menos haya unas pautas-las de las ficciones, las de los "protagonistas" - por las cuales la gente tienda a conducirse y regirse, en una especie de imitación inconsciente o interiorizada de las ficciones. En el caso de la Navidad no veo, sin embargo, tan positivo el fenómeno. Hace demasiados años que nuestras ciudades están malhumoradas [...] Si a este mundo se le exige de repente, a fecha fija, que se conmueva y tenga buenos sentimientos hacia sus semejantes y se reúna con la familia y demás, lo normal es que el resultado sea el contrario del propuesto y deseado [...] por eso yo suelo encerrarme solo en casa a ver vídeos, para refugiarme en la verdadera ficción y huir de esa otra ficción bastarda a la que aún llamamos realidad» ${ }^{11}$.

Las ficciones infiltradas contaminantes "virales" no pretenden ser falsarias (o como suele decirse hoy, un fake), sino sobre todo influir, interactuar, enredarse, mezclarse con lo que llamamos realidad, pero no propiamente hacerse pasar objetivamente por reales. Por su parte, las ficciones infiltradas falsarias -a las que me referiré de inmediato- tienen una carga de fondo más aparentemente simple y epistémica, conduciéndonos a dudar, una vez que son descubiertas (porque entretanto pasan desapercibidas, camufladas), de si en lo sucesivo estaremos en contacto con algo real o irreal/ficticio. Las ficciones infiltradas contaminantes sólo embaucan o embrujan. Que uno reconozca el peso de Qué bello es vivir o

${ }^{11}$ Marías, J. “Ficciones bastardas”. El País, Semanal, 4 de diciembre de 1994: 8. 
de las letras de mil y una canciones de amor... no es reconocerse propiamente engañado, como si se hubiese suplantado la realidad, sino más bien hechizado.

\section{II.2. Ficciones infiltradas falsarias}

Otro tipo de problemática surge cuando hay un empeño específico en el fraude o el engaño, cuando se hace (o es hecho) pasar por real lo que no es sino irreal/ficticio. La ficción en sí misma es una verdadera ficción, por supuesto, pero de cara al receptor que ignora su génesis se hace pasar su contenido por realidad, para lo que es imprescindible una cierta precariedad epistémica en los recursos generales, de todo orden, que permitiesen distinguir realidad y ficción, aparte de la intención de fraude o engaño.

Dentro de las ficciones infiltradas falsarias unas son bastante asépticas y otras, sin embargo, emocionalmente muy cautivadoras, pudiendo en los dos casos darse, según la ocasión, la oportunidad de apropiarse el valor de "veracidad". En el primer caso, se gana en veracidad cuando se organiza el argumento o la estructura de un modo muy coherente y con contundencia (hasta el punto de que un excesivo empeño en conmover empáticamente podría resultar sospechoso ${ }^{12}$ ). En el segundo caso, por el contrario, la ficción infiltrada falsaria potencia su suplantación de lo real no sólo por su coherencia, que siempre es requerida ${ }^{13}$, sino por ser emocionalmente muy "cautivadora", contribuyendo enormemente la empatía al efecto "tridimensional" high definition, reforzándose los contenidos justamente por ese reducto último de la empatía a que antes me referí.

Estas ficciones infiltradas falsarias no serán tanto orientadoras, como las "contaminantes", sino potencialmente muy desestabilizadoras, en la medida en que se tornan desconcertantes y fraudulentas justamente por el dominio de las claves retóricas y emocionales, es decir, cuando son capaces de ser hiperreales (o, si preferimos, hiperverosímiles) y superempáticas, hasta el punto de poder herir a la percepción de lo real en su núcleo íntimo.

Veamos dos casos muy ilustrativos. En ¿̇Por qué la ficción? ${ }^{\text {14 }}$, Jean-Marie Schaeffer comenta extensamente el caso suscitado cuando en 1981, cinco años después de haber escrito una biografía sobre Mozart, Wolfgang Hildesheimer

12 Esta problemática se ha planteado en la historiografía respecto a cuáles serían los más adecuados recursos narrativos y retóricos para la aproximación a acontecimientos extremos, como, por ejemplo, los relacionados con los campos de exterminio. Cfr. Macón, C. y Tozzi, V. "El acontecimiento extremo: experiencia traumática y disrupción de la representación histórica". En La comprensión del pasado. Escritos sobre filosofía de la historia (M. Cruz y D. Brauer, comps.). Barcelona, Herder, 2005, pp.: 111-132.

13 Como un texto breve y muy ilustrativo respecto a la importancia narrativa y ontológicoepistémica de la coherencia, cfr. Leibniz, G.W. "Sobre el modo de distinguir los fenómenos reales de los imaginarios". En Escritos filosóficos (E. de Olaso, ed.). Buenos Aires: Charcas, 1982, pp.: 265-270.

14 Schaeffer,J.-M. ¿्ढor qué la ficción? Madrid: Lengua de trapo, 2002. 
publicó Marbot. Eine Biographie $e^{15}$. Remito al lector interesado a los detalles del caso. Lo cierto es que el minucioso relato de la vida del tal Marbot era la biografía imaginaria de alguien que no había existido, fruto del conocimiento histórico de Hildesheimer, traspasado por su imaginación. Manifestando sorpresa ante la circunstancia de que no se hubiera reconocido-ni siquiera por parte de críticos e historiadores-que su Marbot era imaginario, Hildesheimer dijo que nunca pretendió embaucar a nadie, y que había algunas marcas (a juicio de Schaeffer muy insuficientes) para reconocer que se trataba de una ficción. Lo que venía a probarse era la extraordinaria verosimilitud del personaje y la excelente reconstrucción histórica llevada a cabo por Hildesheimer. Pues bien, Schaeffer comenta con detenimiento por qué lo que debería haber sido leído como una ficción fracasó en tal sentido, pues el texto de Hildesheimer fue leído como si fuese histórico. Señala como muy relevantes en todo ello el contexto autoral, el paratexto, la mímesis formal y la contaminación del mundo histórico por el mundo ficciona ${ }^{16}$. Lo interesante, en cualquier caso, es que siendo un producto ficcional, Marbot es introducido por Hildesheimer en un mundo histórico claramente identificable y referencial con, como solemos decir, "pelos y señales". Por tanto, no se trata de una biografía histórica ficcional (como cuando un personaje histórico es elaborado ficcionalmente: por ejemplo, La muerte de Virgilio, de H. Broch), sino de una biografía ficcional historizada ${ }^{17}$.

La conclusión principal del comentario de Schaeffer al caso Marbot se refiere a la importancia que debe atribuirse al marco pragmático, porque en los casos de verosimilitud muy eficaz, y a falta de dicho marco, sería muy difícil, y a veces imposible, distinguir un texto ficcional de otro factual. Pues bien, si el caso de Marbot es interesante, el de Jimmy's World lo es más, y más provocativo. "Marbot" es, al fin y al cabo, un personaje histórico, y difícilmente podría suscitar la adhesión empática que suscitó Jimmy, y además, no convocaría a nadie a interactuar realmente con él salvando la distancia histórica, humanamente infranqueable. Sin embargo, con Jimmy fue diferente, en la medida en que la infiltración ficcional falsaria fue total y muy hiriente. En la categoría de "Reportaje", el 13 de Abril de 1981 se concedió el Premio Pulitzer a un relato que había aparecido el 28 de Septiembre de 1980 en The Washington Post titulado El mundo de Jimmy (Jimmy's World) firmado por la joven periodista Janet Cooke ${ }^{18}$. Con enorme elocuencia y expresividad, el texto hablaba sobre la vida de Jimmy, un niño adicto a la heroína desde los ocho años, y de su entorno cotidiano y familiar. Era un texto perfecto, bien escrito, tremendamente convincente, con detalles muy dramáticos y extraordinariamente conmovedor. Tan es así, que cuando apareció

15 Hildesheimer, W. Marbot. Eine Biographie. Frankfurt: Suhrkamp, 1984.

16 Schaeffer, J.-M. op. cit. p.: 124-128.

${ }^{17}$ Ibid., p.: 125.

${ }^{18} \mathrm{Se}$ puede encontrar el texto en http://www2.uncp.edu/home/canada/work/markport/lit/ litjour/spg 2002/ cooke.htm. 
el texto, el Ayuntamiento y algunos policías manifestaron interés por encontrar a Jimmy para intentar ayudarle... Tras una serie de indagaciones, y después de que se levantaran ciertas sospechas, se descubrió finalmente que "Jimmy" era un personaje ficticio creado por Cooke, no una persona real. Tras el consiguiente escándalo, de inmediato se retiró el Premio a la autora. Cooke no podría haber aducido, como Hildesheimer, que ella no quería engañar a nadie respecto a si Jimmy existía o no. Y tampoco había pruebas de que hubiera querido llevar a cabo alguna suerte de experimento didáctico o artístico. Mientras que Marbot queda más indeterminado por lo que al entorno pragmático se refiere, el marco de Jimmy's World viene prefijado de una forma inequívoca.

El poder de la verosimilitud en Marbot o en Jimmy es desafiante en la medida en que sus verdades irreales, en cada caso (sobre todo la de Jimmy, pues su verdad queda en el texto elevada a emblema existencial), hieren las excesivas expectativas depositadas en la identificación entre realidad y verdad, como si aquélla fuese dueña de ésta.

No tanto el fraude que había tenido lugar, sino el proceso creativol deconstructivo implicado en el caso-Jimmy habría requerido una-si se me permite la expresión coloquial- "unidad de intervención rápida" compuesta por periodistas, ficcionadores, poetas y pensadores (filósofos) no para oponerse a la restitución del Orden y de la Norma/Límite por la simple operación de denuncia, castigo y restauración del prestigio del medio periodístico, sino más bien para compensar la amenaza de que el proceso transcurriese de un modo trivial, apresurado e irreflexivo. Así pues, esa re-intervención no debería entrar en escena -al menos tal como la imagino- con vistas a sembrar diabólicamente confusión alguna, sino con el fin de aportar un poco de lucidez en torno a cómo la realidad no puede apropiarse de la verdad, paso previo al intento de legitimación de la ficción como mediadora eficacísima, en muchos casos, de verdades irreales. Después de todo, asociar la verdad a lo real acontecido, jes tan fácil...!, pero vincular la verdad a lo no-acontecido, ¡eso exige no simplemente percibir, sino imaginar-y-pensar! Éste es, pues, el tema.

Jimmy's World es un claro ejemplo no únicamente de la autonomía de lo ficcional, sino también de su validez por lo que se refiere a su eficacia veritativa. Filosóficamente, quizás lo más interesante no sea lo meramente falsario de la ficción de Cooke, sino el contexto pragmático del fraude y, sobre todo, en nuestro caso, su potencial de esclarecimiento no sólo del potencial veritativo de la ficción, sino de cara al desdibujamiento crítico, experimental y creativo de los límites proteccionistas y segregacionistas que tienden a separar realidad e irrealidad (ficción) con el consiguiente intento de apropiación de la verdad por parte de la (presunta) "realidad" y su "relato". Puede olvidarse con facilidad y comodidad que lo falsario no es el relato y su intrínseca virtud, sino algo extrínseco al relato mismo, como es el fraudulento disimulo de su ficcionalidad. Y puede olvidarse, 
asimismo, que este disimulo no podría lanzar la fuerza de verdad irreal de lo narrado al pozo de lo "simplemente-falso". Este error no sería menos graveaunque sí pertenecería a un ámbito muy distinto-que el fraude de Cooke. Y sin embargo, el paso por la experiencia del ser-defraudado es filosóficamente decisivo. Jimmy's World es un genuino prototipo de verdad irreal que se nos patentiza a partir de una ficción infiltrada falsaria, provocando una herida o sangrado terapéutico, o incluso, si preferimos decirlo de otra manera, una suerte de microintoxicación homeopática con un veneno necesario.

Lo interesante e inquietante es la posibilidad que brinda no simplemente la eficacia veritativa de la ficción, sino esa misma eficacia en ficciones infiltradas disimuladas o falsarias. Entonces, el Se non è vero, è ben trovato queda condensado en el è ben trovato, pudiendo prescindirse filosóficamente del se non è vero, que propiamente debería ser reformulado como un se non è reale. En tal caso, lo importante sería atenuar la diferencia entre ficción y realidad a partir de ficciones infiltradas contaminantes o, en lo que atañe a la referencia-a-lo-real/irreal y a las posibilidades eficaces de decir-la-verdad, trabajar con las oportunidades experimentales de ficciones infiltradas falsarias, no, en absoluto (ya lo hemos dicho), con una pretensión sofística sino, por el contrario, con una inequívoca vocación epistémica-y-existencial de verdad, mucho más que de realidad, contra el abuso de la ideología realista cuando limita y empobrece lo verdadero. Por tanto, el uso de las ficciones infiltradas falsarias sólo sería admisible a título didáctico o experimental. Aquellas ficciones comenzarían con un fingimiento serio para de inmediato pasar a un fingimiento lúdico y, ulteriormente, un fingimiento compartido epistemológicamente relevante.

En el caso de Jimmy's world, todo el peso de la crítica se hizo recaer sobre la autora. El propio título del acertado comentario de García Márquez al que en un momento me referiré: ¿Q Quién cree a Janet Cooke?, lo dice todo acerca del carácter de la noticia sobre el escándalo provocado por Cooke. Por el contrario, imaginemos que el Premio Nobel colombiano hubiese escrito algo así como Verdades irreales... o incluso, más provocativamente: Toda realidad es verdadera, pero (por suerte) no toda verdad es real. $\mathrm{O}$ incluso: Con perdón, bendito engaño... claro está que advirtiendo en todo momento que el fin no sería el desprestigio del medio periodístico, al que en el fondo le hizo un servicio indirecto Cooke para que pudiera seguirse recordando que el periodismo se debe a la verdad real, o a la realidad verdadera, que repugna del engaño y que la "profesión" es al noventa y nueve por ciento (el uno por ciento sería la "oveja negra" Cooke) honesta y digna de toda confianza—se dirá.

Aunque Marbot. Eine biographie con todos sus disimulos (según su autor, involuntarios) provoca un desafío en la medida en que nos recuerda que increíblemente la comprensión histórica no requiere de verdades reales, es de baja intensidad comparado con el que plantea Jimmy. La cualificación de "realidad" aumenta su intensidad cuando están en juego la proximidad, es decir, 
la accesibilidad y la empatía. Y por otra parte, el contexto. Después de todo, mientras que a Schaeffer le asiste la duda acerca de su verdadera intención, esta duda no es posible respecto a Cooke—como ya dije-, porque su engaño está fortísimamente marcado por a) la circunstancia de un Premio en un contexto de veracidad periodística, donde se sobrevive, a veces con trabajo, sólo bajo las galas de la veracidad y la honestidad...; b) que lo que se había de premiar era un reportaje y c) en un premio con enorme prestigio (con evidente repercusión). En cualquier caso, el relato de Cooke es existencialmente neutro, la validez de lo narrado es incontrovertible, y su veracidad no depende de que ningún individuo real pudiese implementar a "Jimmy" en concreto.

Así pues, respecto a Jimmy's World, la oportunidad que se pierde de cara a la "opinión pública" radica en que lo interesante habría sido insistir no tanto o no sólo en el engaño, absolutamente antiguo, vulgar, sino en el aprendizaje de a) la retórica del efecto-realidad ${ }^{19}$, b) la precariedad de las fronteras o su porosidad, y, lo más positivo, c) la posibilidad de las verdades irreales. ¡Pero habría resultado muy arriesgada esta condescendencia "filosófica"!

La posibilidad de verdades irreales es una de las genuinas raíces de la valiosa necesidad de la experiencia literaria, pero no tanto como una experiencia en la que nos entregamos ociosa y placenteramente a una historia o conjunto de anécdotas imaginarias más o menos entretenidas. Eso sería tan sólo el aspecto más superficial de la Literatura (por más que resulte muy popular). Más bien se trata del camino indirecto: de reconocer que la sacrosanta realidad, tan firme y cierta, tan irrefutable y contundente, tan adherida a las certidumbres del al pan, pan y al vino, vino y del más vale pájaro en mano que ciento volando... sin embargo no agota, ni siquiera garantiza, la comprensión más (humanamente) valiosa de la verdad, que sin duda es más que la recortada o rebajada percepción de lo real. Por eso se hace preciso reivindicar el momento de la ficción novelesca o dramatúrgica, o del texto poético, tan profundamente indeterminado, "límbico", en su tierra de nadie. A este respecto, es fundamental la tesis de Kundera acerca de la novela como exploradora de la existencia (cfr. el texto breve del autor que encabeza este estudio).

\section{Adenda. MONTAJES VERDADEROS}

Las verdades irreales no se dan sólo en el ámbito textual, por supuesto. La fotografía de Robert Capa Muerte de un miliciano (1936) puede ilustrarlo perfectamente. Como en los anteriores casos, no puedo ocuparme aquí de la historia de la fotografía ni de quienes han creído e intentado demostrar que fue verdaderamente tomada en el instante en que cayó herido de muerte el miliciano,

${ }^{19}$ Sin duda sigue siendo útil releer a Barthes, R. "El efecto de realidad". En AA.VV. Lo verosimil. Buenos Aires: Tiempo Contemporáneo, 1970, pp.: 95-101. 
ni de quienes han llegado a sospechar que fue un montaje preparado para servir de propaganda del bando republicano en la recién comenzada Guerra Civil. Por otra parte, para mayor complicación y mistificación, se han generado debates (humanamente comprensibles, pero estético-filosóficamente irrelevantes por completo) acerca de la identidad del miliciano, de las que obviamente no me ocuparé aquí. El lector interesado podrá encontrar por doquier información al respecto. Lo único realmente decisivo, desde un punto de vista filosófico fue/es la fotografía misma en su instante, pero un instante que no es el instante temporal, sino el instante de la Imagen (por sí) misma y el significado que transmite, que (me temo, o quizás sería mejor decir que me congratulo de que) sólo se capta desde dentro de la imagen, incluso (y mejor si sólo) con un mínimo de preguntas en torno a lo que rodea a la imagen como tal. Podemos identificar al soldado, ubicar con milimétrica exactitud el lugar y la hora del suceso, determinar y objetivar sin fin, desde luego, y es muy comprensible que todo ello pudiera resultar de interés en ciertas circunstancias y para ciertos "agentes epistémicos", pero no creo que en verdad nada de ello fuese esencial a la fotografía misma. Y en cualquier caso, ¿qué hay que decir?: ¿qué Capa habría sido un mago del foto-montaje y del encuadre? ¿o apreciar la increíble, casi circense rapidez en el disparo fotográfico?, ¿o tal vez valorar su suerte? Lo cierto es que cuando se entra a evaluar la fotografía, se corre el riesgo de dejar de atender a su poderosa verdad irreal para, neciamente, pasar a considerar sólo (afirmativa o negativamente) su Referente Real. ¡Pero ni siquiera en el caso de la fotografía estaríamos autorizados a esta pereza del sí o del no de ese referente real, siendo que la Fotografía parece siempre más proclive al Si-del-referente-real! Como en el caso de Cooke, si acaso Capa mintió, sencillamente no debió mentir (insisto en que no entraré a discutirlo) acerca de que lo que capta la fotografía no aconteció realmente... Pero entonces, dirán todos, ¡su fotografía carecería de valor! Triste suerte.

Por lo que se refiere a una cierta perspectiva filosófica, se me permitirá una vez más-no sé si considerarlo un desliz, una provocación, una transgresión o un despropósito por indiferencia—que no conceda tanta importancia a la cuestión de si la fotografía fue o no un montaje, etc., en la medida en que creo que es necesario no olvidar lo esencial: lo que muestra la fotografía aconteció, aunque tal vez no de hecho. ¡Aconteció allí donde acontece toda fotografía que no es mera casualidad: en el pensamiento de Capa, un pensamiento que lejos de poder ser tachado de "meramente subjetivo", acertó plenamente llegando a crear una de las imágenes más emblemáticas del siglo XX! La fotografía transmite una perfecta verdad irreal. Todo lo que en verdad sucedió y sucede en "una guerra" está ahí concentrado, imantado por la Imagen ${ }^{20}$, y en el peor de los casos, si estuviese el prestigio de Capa en juego, se le podría seguir elogiando por su mirada, por

20 Sobre esta cuestión, cfr. Moreno, C. "Neutralidad e infinito. Propedéutica fenomenológica sobre la Imagen y el Acontecimiento". Boletin de Estudios de Filosofía y Cultura Manuel Mindán, 8 (2013): 41-71. Hay versión online. 
su imaginación, por su "ocurrencia", o por su montaje genial. Una fotografíanoema perfecta. Que no nos importe si lo que muestra existió de hecho, puede ser tomado como ingenuidad, desprecio o falta de tacto por nuestra parte... Pero también es cierto que las cuestiones relativas a si el acontecimiento ocurrió en realidad o si la identidad del miliciano era realmente tal o cual pueden resultar no ya inapropiadas, o al menos superfluas, sino incluso insultantes respecto a la verdad profunda que transmite la Imagen: un soldado (por supuesto, el Soldado Desconocido) que cae muerto en el horizonte de la atrocidad de la Guerra. Ciertamente, todo lo demás pasa a ser secundario. ¡Y en verdad, así es! Todo lo demás nos distrae del poder de convocatoria y de verdad inmanente de la Imagen, nos entretenemos con Robert Capa, con el suceso "real" y con la identidad del soldado... Por fortuna, en este caso, como en el de Jimmy's World, la intensidad del Relato o de la Imagen resiste a cualesquiera distracciones... pero es cierto que por éstas puede extraviarse una oportunidad extraordinaria para comprender la comparecencia en la Imagen o en el Relato de una trascendencia no sometida a la dualidad real/irreal.

\section{UNA NUEVA TRASCENDENCIA}

Con el juego-o con la farsa-de Jimmy's World viene a recordársenos hasta qué punto la deuda con la referencia real, especialmente cuando se la pretende objetivar a toda costa, puede degenerar de modo que el prestigio que inicialmente se otorgara a lo real se torne a la larga gravamen y pérdida de profundidad o de proximidad a una verdad que requeriría el auxilio justamente de recursos que sobre todo procedieran de la zona de las verdades irreales ficcionales, en la que se desenvuelve con especial destreza la experiencia literaria (básicamente, el relato novelesco). De esta inquietud a la que me estoy refiriendo vino a hacerse cargo, en su momento y aún hoy, el así llamado Nuevo Periodismo. Pocos días después de concedido y retirado el premio (el 15 de Abril de 1981), en El País del Miércoles 29 de Abril, Gabriel García Márquez escribió un texto titulado ¿Quién cree a Janet Cooke?, en el que leemos:

«En todo caso, más allá de la ética y la política, la audacia de Janet Cooke, una vez más, plantea también las preguntas de siempre sobre las diferencias entre el periodismo y la literatura, que tanto los periodistas como los literatos llevamos siempre dormidas, pero siempre a punto de despertar en el corazón. Debemos empezar por preguntarnos cuál es la verdad esencial en su relato. Para un novelista lo primordial no es saber si el pequeño Jimmy existe o no, sino establecer si su naturaleza de fábula corresponde a una realidad humana y social, dentro de la cual podía haber existido. Este niño, como tantos niños de la literatura, podría no ser más que una metáfora legítima para hacer más cierta la verdad de su mundo. Hay por lo menos un punto a favor de esta coartada literaria: antes de que se descubriera la farsa de Janet Cooke, varios lectores habían escrito a su periódico para decir que conocían al pequeño Jimmy, y 
muchos decían conocer otros casos similares. Lo cual hace pensar -gracias a los dioses tutelares de las bellas letras- que el pequeño Jimmy no sólo existe una vez, sino muchas veces, aunque no sea el mismo que inventó Janet Cooke. [...] John Hersey, que era un buen novelista, escribió un reportaje sobre la ciudad de Hiroshima devastada por la bomba atómica, y es un relato tan apasionante que parece una novela. Daniel Defoe, que era también un gran periodista, escribió una novela sobre la ciudad de Londres devastada por la peste, $y$ es un relato tan sobrecogedor que parece un reportaje. En esa línea de demarcación invisible pueden estar los ángeles que Janet Cooke necesita para la salvación de su alma. Pues no habría sido justo que le dieran el Premio Pulitzer de periodismo, pero en cambio sería una injusticia mayor que no le dieran el de literatura» ${ }^{21}$.

Sería una pregunta muy interesante para ser debatida la de si el relato de Jimmy's world podría encuadrarse bajo el rótulo general de "nuevo periodismo"marginando, por supuesto, la cuestión del fraude. Dejaremos esta cuestión a expertos, permitiéndonos tan sólo un rápido comentario, pues lo que más me importa es rescatar la relevancia de las verdades irreales de cara a la verdad. No es descabellado suponer que, en cualquier caso, el relato de Cooke pudo haberse gestado en el horizonte de las opciones de estilo, retóricas y cognitivas abierto por el New Journalism, en el que lo real es conducido a la ficción buscando una verdad más profunda, trascendente y penetrante, más humana y filosófica, más narrativa y poética, con más intenso esprit de finesse. Ciertamente, ¡todo un lujo si fuesen bien aprovechadas las posibilidades! Una vez más: situados en el plano más o menos consensuado en torno a lo meramente real, lo que separa un relato como $A$ sangre fría, de Truman Capote, de otro como Jimmy's World es que aquél trabaja con personas y sucesos de los que se dirá que son/fueron reales, de los que Capote extrae sus posibilidades o desarrollos ficcionales. Por lo que se refiere a Jimmy's World, ¿parte Cooke de una persona-real-existente que luego fuese ficcionalizada? Ciertamente, como individuo, Jimmy no existe, no es real. ¿Pero, acaso no es verdadero? Si vamos pidiendo documentos de identidad y "pelos y señales", la cuestión está resuelta: Jimmy no es real. Pero resulta que ¡es más que real: es verdadero!, y deja muy atrás a cualquier hipotético Jimmy de carne y hueso, con nombre-y-apellidos, aquí y ahora, o en tal momento, éste: el mismísimo Jimmy en persona: éste, y no otro, "el del $3^{\circ}$ izquierda". Cuando los policías manifestaron la intención de encontrar a Jimmy, Cooke podría haberles respondido al estilo de lo que dice García Márquez en su texto: que "Jimmy" había muchos, que era/es una multitud. Parece que la realidad a partir de la cual la ficción (realista) trabaja es sólo el ente del que se predica que es "real", y no también, e incluso sobre todo, lo que sabemos verdaderamente de la realidad, que abre las puertas—ese saber-de lo que llamamos "verdadero"...

21 Vid. http://elpais.com/diario/1981/04/29/opinion/357343203_850215.html 
Si un receptor no es capaz de reconocer la procedencia "real" del relato, en el caso de la ficción realista, que es la más fácilmente disimulable, acabará por creer que al menos la base del relato es ficcional, siendo en verdad una reelaboración literaria de un hecho real, con poderosos aditamentos ficcionales, pero no propiamente una ficción (al revés que el caso de Marbot). Esto puede suceder. En efecto: tanto puede la ficción absorber la realidad, que cuando en otra ocasión quiera reafirmarse la ficción realista como ficción, habrá que decir que «el personaje $\mathrm{X}$ es ficticio. Cualquier parecido con la realidad es pura coincidencia».

El caso de Jimmy's world es el contrario. No se trata de que se lea un texto ficcional sin saber que es una reelaboración estilística de un relato sobre lo real, sino de que se lee un texto como si se tratase de un relato acerca de lo real, cuando en verdad es una ficción. Que la ficción coincida con la realidad puede ser pura coincidencia porque lo posible (ficcionalizable) es más amplio que la realidad, de modo que habría que advertir que si algo ficcional se parece demasiado a lo real, no es necesariamente porque haya procedido de lo real o buscado "descender" a lo real, sino porque es una coincidencia que un elemento del conjunto de lo posible/ficticio también pertenezca al subconjunto de la realidad. Con ello se pretende librar a lo ficcional de contaminaciones hiperrealistas que tentasen al receptor a ir desde el relato a la realidad; así como librar a la realidad de esas reelaboraciones ficcionales. Pero que la ficción se infiltre en lo real es más grave. ¿Qué tendría que haber dicho Janet Cooke para ser honesta?: «[Jimmy no es real, pero] cualquier parecido con una mera ficción es pura coincidencia». Sería un poco absurdo. Al decirlo vendría a significarse que por no-ser-real Jimmy podría ser asignable sin más a lo simplemente ficticio (entiéndase: segregado, devaluado) y que, por así decirlo, ahí acabaría todo. Pero entre el no-ser-real y el ser meramente ficcional (en sentido restrictivo/despectivo) se encuentra justamente la verdad irreal. De esto es de lo que se trata en Jimmy's World: de una verosimilitud que no se debe a la realidad (como ocurre en $A$ sangre fría), sino a la verdad y por eso nos "captura". El relato de Cooke es tremendamente verosímil no porque se parezca a lo real o haya arrancado de lo real, sino porque se parece enormemente a lo-que-sabemos-verdaderamente-de-la-verdad (de la que lo real es un modo de ser o de presentarse). No, "Jimmy" como personaje no encontrará como referente ningún Jimmy de hecho, pero se parece muchísimo a "Jimmy" como posibilidad esencial, extremadamente verdadera, de ser en el mundo. Muy en su papel, el jurado del Pulitzer creyó que recompensaban o premiaban el que Cooke hubiese encontrado a un Jimmy real y hubiera escrito muy bien sobre su vida. Cooke, por su parte, podría haber escrito al final de su relato, con letra muy pequeña «immy no es real, pero es muy verdadero (Se non è vero, è ben trovato22)».

22 Hay que evitar la confusión con el uso del "vero" en el conocido dicho. Propiamente, nosotros deberíamos decir, aquí: se non è reale, è ben trovato. 
Justo a esta "trascendencia" de lo bien-hallado quería que llegásemos. Jimmysin-Jimmy disfruta una poderosa verdad irreal, a la que hemos accedido por la vía de la ficción (en este caso, hiperrealista y plena de verosimilitud). Lo que se consiguió con el Nuevo Periodismo fue un cuando menos estimulante género híbrido que no se conformaba con el establecimiento policíaco-judicialnotarial del muro o de los límites de separación entre Ficción y Realidad, entre Literatura y Periodismo. La verdad era y es algo demasiado valioso como para dejarlo en mano de notarios y policías de lo real (ocupación a veces asumida por los periodistas e imitadores secuaces ${ }^{23}$ ). El caso de Jimmy's World supuso no sólo un fraude-que lo fue-, como tantos otros pueden darse, sino una herida en el orgullo del Pulitzer Prizes, del Washington Post y del Periodismo en general frente al Super-Yo de la realidad-y-veracidad, para el que el atrincheramiento en la realidad es decisivo, sin que se cuestione demasiado que lo verdadero no está sometido a lo real..., aunque nuestro fetichismo del Realitätsprinzip nos lance inercialmente a prestigiar continuamente lo real en cuanto real... por ser ya portador de verdad (no importa si pobre y recortada: verdad en suma), de modo que ese mismo fetichismo, aliado con la policía de lo real, declarase non grato y perseguible de oficio al que recordase su precariedad. Confundimos con demasiada frecuencia verdad y realidad porque no cabe duda de que ésta es más accesible y, si se me apura, más computable y dominable que aquélla. Sin embargo, no sólo se trata de que la verdad sea más decisiva que la realidad, sino de que la verdad esté abarrotada de verdades irreales ficcionalmente accesibles. Entre otras cosas, lo que viene a probar Jimmy's World es la posibilidad de que hubiese un espacio intermedio, una suerte de No man's land en la que pudieran circular libremente los discursos a cambio no de una mimética, ni siquiera una verosimilitud fáctica, sino de una verosimilitud de orden superior, que abarcase también lo que resultara inverosímil respecto a lo meramente real...

Cuando se ganara ese terreno, habríamos alcanzado acaso: a) una enorme confusión, dirían algunos. Sin duda, esta inquietud surgiría en el terreno de los prestigios y nombradías de la percepción de lo real, porque es del lado de esta percepción donde se acumula - para ser cuestionada - toda la estabilidad, la consistencia o la contundencia del principio de realidad y sus acólitos incondicionales; o bien, b) una gran lucidez, conseguida a partir de una desestabilización ficcional de la mera realidad, permitiéndosenos el acceso a la verdad en una zona neutra de verdad entre realidad y ficción.

${ }^{23} \mathrm{Ni}$ que decir tiene que estoy pensando únicamente en los malos periodistas. 


\section{PREPARATIVOS PARA UNA INTRODUCCIÓN A LA MODIFICACIÓN DE NEUTRALIDAD. EL EFECTO-EXTRAÑAMIENTO.}

Incluso siendo ficcional—por ejemplo,si Cooke se hubiera decidido a presentar su relato a un concurso literario-, Jimmy tiene vocación de parecer real. Para ello, aparte del parecido, tiene que ser capaz de suscitar un fuerte vínculo empático, y a tal efecto resulta imprescindible sumergirse en la pasión de lo real. ¡Hay que hacer real a Jimmy, que no simplemente lo parezca! Lo que puede debilitar el poder de la ficción es que mientras que la relación con lo que llamamos realidad suele ser primeramente constatativa, aparentando una apertura pasiva y, si se me permite decirlo así, "sumisa", una entrega casi incondicional, sin embargo, la ficción siempre parece acarrear una posible sospecha en la medida en que en cuanto ficción no se puede obviar su procesualidad intencional y las sospechas que cabría inferir de su libertad. Las ficciones intencionadas como tales deben ser creadas. No debería, pues, extrañarnos que pareciera como si la ficción, para triunfar en su verdad y potenciar sus contenidos debiera autoinmolarse como proceso ficcional. Así pues, no sería descabellado imaginar que la primera presencia de Jimmy hubiese sido puramente ficcional, y que sólo tardíamente surgiese el Jimmy "imaginario-real" suplantador del "imaginario-ficcional”, el Jimmy "real", que acabase seduciendo a Cooke para que lo hiciera real por arte de la magia de la escritura, nada más y nada menos que en un periódico como The Washington Post y de cara al Premio Pulitzer...jJimmy quiere ser (entiéndase, clamaría la actitud natural: quiere-ser-real, ¿o acaso ser no es = ser real? ) y susurra diabólicamente al oído a Cooke, con insidiosa insistencia, para que le haga real, que le conceda "vida"! Si se hubiera presentado como ficción, aunque fuese una ficción hiperrealista o la mejor de las ficciones, habría visto de inmediato rebajada su intensidad desde el punto de vista cognitivo y emocional. Jimmy aparecería no sólo como irreal, sino distante... Se diría “¡Pobre niño!” y poco más: "una ficción más". En el fondo, en ultimísima instancia y "relajadamente": todo ha sido, es en broma ${ }^{24}$, tan sólo un sueño...

24 Con vistas a ciertas prácticas desestabilizantes o deconstructivas, podríamos dejarnos guiar por otro caso bien llamativo y de rancio abolengo, en el que el parecido de la ficción con lo real no es pura coincidencia, sino todo lo contrario: coincidencia pura. Se recordará que en Hamlet, de W. Shakespeare, Hamlet manipula la obra que unos actores van a representar en el castillo, a saber, $E l$ asesinato de Gonzago, a fin de que pueda mimetizarse en la escena lo que a su juicio ocurrió con el asesinato de su padre por su tío. Este, cuando se represente la pieza, sin percatarse de la artimaña (conducir desde la ficción a la realidad), no podrá dejar de empatizar con lo representado (que le recuerda lo realmente acontecido) y mostrará signos de que se está viendo reflejado. Eso es lo que espera Hamlet. Y así ocurre. El tío de Hamlet se azora e inquieta enormemente, a lo que Hamlet le dice (irónicamente) que no se preocupe (por si se inquieta por lo representado en la escena), pues allí, en la obra de teatro, los actores, "envenenan en broma". 
En cualquier caso, ¿y si no hubiésemos partido, de entrada, de la dicotomía ni del enfrentamiento dialéctico en torno a prevalencias, derechos y prestigios de lo real e irreal como una especie de presupuesto indiscutido? Tarea difícil, casi imposible o utópica, pues ¿acaso no estamos como incrustados, inmersos o casi hipnotizados por la atracción de lo real y atrapados por sus dialécticas? Y sin embargo, tal vez fuese viable alguna estrategia para atenuar ese deseo, un "artefacto" metódico de des-realización, pero también de desficcionalización para probar, si fuese posible, otra lucidez.

La enseñanza de Jimmy's World radica en aquello en lo que nos instruye nuestra decepción precisamente cuando se desliza desde la sorpresa perpleja a la admiración inteligente. Nos enseña no tanto que podemos ser engañados (momento de la experiencia negativa, muy conocido), de modo que para la siguiente ocasión deberíamos estar prevenidos, sino que hay ciertos engaños que nos hacen indiscutiblemente más sabios ${ }^{25}$. Hemos llegado nada más y nada menos que a vislumbrar filosóficamente que-como en el caso que nos ocupael engaño respecto a lo real no equivale al engaño respecto a lo verdadero. $Y$ lo más decisivo tal vez, que requeriría de nosotros máxima lucidez filosófica: que de lo verdadero, o para ser más preciso, de su "producción" puede formar parte justamente esa diferencia de inequivalencia, que la llevemos a cabo, que la experimentemos, que la suframos, asistida por el desplazamiento desde lo verdadero a lo ficcional. Entonces, incluso podríamos apurar el argumento y decir que lo verdadero sólo ha aparecido propiamente gracias a ese engaño (o a nuestro error). Dado el texto, su pasmosa positividad, el texto-mismo26, ¿quiénes podrían exponerse a ser engañados? Los que se dejaran guiar no por el texto,

El doble juego del pérfido Hamlet es total. Lo que aquí me interesa destacar -y que creo que puede ayudarnos a irnos introduciendo en la problemática de la modificación de neutralidad- es que ni el tío de Hamlet, forzado por su artimaña, está siendo (a su pesar) buen espectador, en la medida en que está mordiendo el cebo hamletiano y transitando impuramente desde la ficción a la realidad, contaminando la escena con su circunstancia personal, ni Hamlet, con su juego, está siéndolo tampoco, pues lo que dice no es cierto dentro de la escena, sino sólo en el entre lúdico (véase nuestra referencia a Lotman) de la escena + patio de butacas, confundiendo a tal efecto, irónicamente, lo que ocurre intraescénicamente, donde es cierto que se envenena en serio, pero no los actores, sino los personajes. Del mismo modo, nosotros, los que asistimos a la representación de Hamlet, deberíamos valorar que el tío de Hamlet no ha envenenado en serio al rey, sino sólo en broma, del mismo modo que toda la desgracia de Hamlet es en broma (Cfr. Shakespeare, W. Hamlet. En Hamlet/Macbeth. Barcelona: Planeta, 1980, p.: 63).

${ }^{25}$ En varias ocasiones he narrado un engaño/fraude/broma al que asistí en mi infancia, cuando un profesor propuso al curso que los que quisieran ver las carretas del Rocío, que iban a desfilar por la Gran Vía de Huelva (estoy hablando de comienzos de los 70 del siglo pasado), salieran al pasillo. Acto seguido - resumo la anécdota—sacó de su bolsillo un fajo de tarjetas postales de las susodichas carretas, instando a mis compañeros, perplejos, a volver a la clase. Vid. nuestras referencias en la nota 6 .

${ }^{26}$ Para una tentativa respecto al texto mismo, cfr. Moreno, C. "Filosofía primera y texto mínimo. Reducción fenomenológica y acto de leer”. En Radicalidad y Episteme (J.Villalobos, ed.), Sevilla: Universidad de Sevilla, 1991, pp.: 107-131. 
sino por el entorno paratextual pragmático de Jimmy's World, que les distrajoes cierto que muy humana y "cultamente"-de atender al "Jimmy" verdadero. Quien hubiese sido diestro en esa diferencia entre real y verdadero (y no porque lo real no sea verdadero, sino porque no todo lo verdadero tiene por qué ser real), quizás se hubiese sonreído por el juego o el experimento.

En buena medida, y respecto a las posibilidades de comprensión de la escena teatral, Bertolt Brecht se esforzó mucho, desde los años 20 del pasado siglo, y con intensidad en la década de los 30 y 40, en una disciplina que permitiese una demora reflexiva antes de ceder toda la confianza al deseo-y-percepción de realidad. Creo, en efecto, que la propuesta brechtiana en torno al $V$-Effekt, a saber, el Verfremdungseffekt o efecto-extrañamiento o efecto-distanciamiento puede resultar provechosa para acercarnos a la extraña zona de la husserliana Neutralitätsmodifikation. De lo que se trata es de entrar en el universo ficcional con un "pureza" más intensa, en este caso, mediante la práctica experimental (pero llevada a cabo con frecuencia) del efecto-extrañamiento, neutralizando el tantas veces no simplemente consentido, sino bien amado y entrañable efecto-de-realidad. Si la propuesta está destinada especialmente al ámbito escenográfico-teatral, es porque sus potenciales plásticos y visuales son mayores.

Brecht desarrolló la práctica del $V$-Effekt en su Kleines Organon, pero también en muchos textos breves, muy repartidos ${ }^{27}$. Pretendía que el espectador asistiese a la obra sin asentir incondicional y acríticamente a la realidad de lo representado, sino tan sólo atento a lo representado como tal, disminuyendo al máximo efectos lumínicos, de vestuario, de decorados, etc. La idea, expresada ejemplarmente del modo más escueto sería: que fuésemos capaces de asistir a la representación de Hamlet, por ejemplo, sin tener que estar continuamente cayendo fascinados por todo lo que en la escena nos hace involucrarnos con el argumento y los personajes como si fuesen reales y la escena no fuera, en verdad, una escena. Se trataría de rebajar en la representación todo aquello que pudiera distraernos hipnóticamente. Ni que decir tiene que esta hipótesis experimental de Brecht rebajaría las expectativas de entrañabilidad empatizante y restaría "calor humano" a la obra, siendo que, como decía Lotman, lo que queremos es "deshacernos en lágrimas ante la ficción". Brecht quería incluso que llegásemos a recordar que son actores los que encarnan a personajes... Sin duda, se trata de una especie de "jarro de agua fría" sobre los potenciales compromisos afectivos de un espectador que lo que quiere es disfrutar, participar, ser algo más que mero espectador. Brecht decía que

«los seres humanos van al teatro para ser arrebatados, fascinados, impresionados, elevados, espantados, conmovidos, cautivados, liberados, distraídos, salvados, animados, sacados de su propio tiempo, provistos de ilusiones. Todo esto es tan

27 Brecht, B. Escritos sobre teatro. Barcelona: Alba editorial, 2010. 
obvio que se suele definir el arte como aquello que libera, arrebata, eleva, etc. se considera que no es arte si no lo hace.

La pregunta es, pues: ¿es posible el arte sin identificación, o sobre otra base que no sea la identificación? ¿Qué podría constituir esa nueva base?

¿Qué podría sustituir el temor y la compasión, el dúo clásico, para producir la catarsis aristotélica? ¿Si renunciamos a la hipnosis, a qué podríamos recurrir? $¿$ Qué actitud adoptaría el espectador en los nuevos teatros si se le negara la actitud ensoñada, pasiva, sumisa al destino? No debería ser transportado, o secuestrado, de su mundo al mundo del arte; por el contrario, debería ser introducido en su mundo real, con todos los sentidos despiertos. ¿Es posible poner en lugar del temor ante el destino el ansia de conocer, en lugar de la compasión la solidaridad? ¿Se puede establecer así un nuevo contacto entre el escenario y los espectadores, podría constituir eso una nueva base para el disfrute del arte?» $^{28}$.

Como en otras ocasiones, y como con respecto a otras problemáticas, Maurice Blanchot da en la clave cuando dice que

«este efecto aspira a sustraer la cosa representada a la adhesión instintiva donde perecen la audición y el sentido. Lo que sucede allá en la escena no es natural, y no debemos tomarlo como verdad cierta ${ }^{29}$. Por una parte, siempre debemos estar en situación de recordar que asistimos a una ficción obtenida por medios artificiales, que el actor es un actor y no Galileo Galilei [...] Asimismo, aquel sol que alumbra, no es la luz del día, sino un proyector, por eso hay que mostrarlo, y el teatro ya no debe disimular lo que es: un conjunto coordinado pero inestable de artificios, un espacio extraño y capaz de hacer extrañas y lejanas cosas que allí se cumplen, de modo que podamos tomar nuestras distancias con estas cosas, pese a lo familiar y lo consagrado que nos parezcan, dejando de considerarlas como naturales, viéndolas al contrario como insólitas, hasta injustificadas, y ya no diremos: "así es, así será siempre”, sino: "así fue, también podría ser de otro modo”.

La gran preocupación de Brecht es la pesantez de las cosas, la apariencia fija y estable de las relaciones humanas, su falso aspecto de naturaleza, la certidumbre que las preserva, la fe en la costumbre, la incapacidad de imaginar el cambio, de aspirar y prepararse a él. Todas sus obras podrían iniciarse por la interpelación que dirigen los actores al principio de La excepción y la regla, memorable advertencia: Debajo de lo cotidiano, descubran lo inexplicable. Detrás de la regla consagrada, disciernan lo absurdo [...] No acepten como tal la costumbre recibida, busquen su necesidad. Se lo rogamos encarecidamente, no digan: "Es natural" ante los acontecimientos de cada día. En una época en que impera la confusión, en que se derrama la sangre, en que se ordena el desorden, en que la arbitrariedad adquiere fuerza de ley, en que la bumanidad se deshumaniza... No digan nunca. "Es natural" a fin de que nada pase por inmutable.

${ }^{28}$ Ibid., pp.: 82-83.

${ }^{29}$ Una vez más, nosotros diríamos "realidad cierta". 
Preocupación que puede parecer más filosófica que artística, si se trata de suscitar la sorpresa para despertar el espíritu de interrogación, luego de observación, luego la libertad de juicio y, si es necesario, el espíritu de rebeldía» ${ }^{30}$.

Mantengamos la ficción como tal en tanto ficción, sin pretender obsesivamente que parezca realidad. Y des-ficcionalicémosla luego. Cuando lo intentemos, habremos ganado no simplemente lo representado menos su "realidad", sino también lo ficcionalizado sin la ficción. Cabe imaginar que entonces, en el terreno neutro alcanzado, estaríamos en condiciones de acceder a una nueva comprensión. Bertolt Brecht llegará a decir que

«algunos escenógrafos empeñan todo su arte en que al contemplar su escenario creamos encontrarnos en un lugar verdadero de la vida verdadera ${ }^{31}$. Pero más bien deberían lograr que creamos estar en un buen teatro. Sí, incluso deberían lograr que, estando en un lugar verdadero de la vida verdadera, creyéramos estar en el teatro. Pues en el teatro ha de enseñarse una manera determinada de ver las cosas, una actitud frente a los acontecimientos analítica, atenta, y una capacidad para ordenar los grupos imprecisos de personas según el sentido de los hechos» ${ }^{32}$.

Desde el punto de vista del aprendizaje, no cabe duda de que si el fingimiento de Cooke se hubiera mantenido como simplemente lúdico, es decir, reconociendo que Jimmy no existía, no habríamos aprendido tanto como cuando al menos experimentalmente (pero en serio) fuésemos engañados, porque aparte de conocer a "Jimmy" hemos debido experimentar el fraude: hacer la experiencia, pero no estética, sino ontológica, de cómo lo que creíamos real es ficcional, pero no como cuando creíamos estar con lo real y nos damos cuenta de que estábamos en un error, sino como cuando un contenido que asignábamos a lo real se desplaza a lo verdadero-irreal (ficcional). ¡No se trataría de una pérdida o de una experiencia negativa o destructiva, sino de una ganancia, en la medida en que comprendiésemos que ni lo verdadero ni lo más verdadero tiene por qué ser real!

\section{UNA APROXIMACIÓN A LA MODIFICACIÓN DE NEUTRALIDAD EN IDEAS I (HUSSERL)}

A la altura de 1913, en Ideas I, tras reivindicar la importancia que la ficción tendría para la fenomenología, Husserl, inmerso en el tema de la correlación noético-noemática, aborda un asunto crucial para la fenomenología de la imagen,

${ }^{30}$ Blanchot, M. "El efecto de distanciamiento". En El diálogo inconcluso. Caracas: Monte Ávila Editores, 1970, pp.: 561-562.

${ }^{31}$ Demasiado pretenciosa, tal vez, la formulación, si nos atenemos a lo que aquí pretendemos dilucidar. Mejor: «en un lugar real de la vida real».

32 Brecht, B., op. cit., p.: 200. 
y para la fenomenología en general, en la medida en que intenta conducir a su culminación la neutralidad existencial que ya desde 1900, en Investigaciones lógicas, se había asignado claramente a los objetos intencionales.

En el camino hacia la tesis en torno a dicha modificación es importante haber reivindicado, casi desde el comienzo, como digo, a) la neutralidad existencial del objeto intencional 33 ; y b) la ficción, como ocurre claramente en Ideas I, de modo que lo decisivo sería la atención que debiera prestarse a la presencia intencionada en cuanto tal... Dice Husserl que para alcanzar las esencias se ha de recurrir a la fantasía (lo que en diversos textos Husserl denomina la libre variación imaginaria); es decir (ya en las proximidades del eidos), no tanto todos los rasgos que podría poseer algo para ser lo que es, sino los que no podría dejar de poseer para ser lo que es. Por ello, en la medida en que opera con estructuras intencionales en las que lo dado es existencialmente neutro y, por otra parte, concede una enorme eficacia a la Umfiktion (circunficción) en torno a variaciones conducentes al eidos, dirá Husserl que

«se trata, naturalmente [...] de ejercitar copiosamente la fantasía en la perfecta clarificación aquí exigida, en la libre transformación de las daciones de la fantasía, pero antes, también, de fecundarla por medio de las más ricas y mejores observaciones posibles en la intuición originaria, sin que esta fecundación quiera, naturalmente, decir que la experiencia como tal tenga una función como fundamento de validez. Un extraordinario provecho cabe sacar de lo que nos ofrece la historia, en medida mayor aún el arte, y en particular la poesía,

33 «Si está presente esta vivencia, hállase implícito en su propia esencia, que quede eo ipso verificada la "referencia intencional a un objeto", que haya eo ipso un objeto "presente intencionalmente"; pues lo uno y lo otro quieren decir exactamente lo mismo. Pero naturalmente, dicha vivencia puede existir en la conciencia con esta su intención, sin que exista el objeto, y aun acaso sin que pueda existir. El objeto es mentado, esto es, el mentarle es vivencia; pero es meramente mentado; y en verdad no es nada. Si me represento el dios Júpiter, este dios es un objeto representado, está "presente inmanentemente" en mi acto, tiene en él una "in-existencia mental" o como quiera que digan las expresiones-erróneas si se las interpreta en su sentido propio-. Me represento el dios Júpiter quiere decir que tengo cierta vivencia [...]. El objeto "inmanente", "mental", no pertenece [...] al contenido descriptivo (real) de la vivencia; no es en verdad inmanente ni mental. Pero tampoco existe extra mentem. No existe, simplemente. Mas esto no impide que exista realmente aquel representarse el dios Júpiter [...]. Si existe el objeto intencional, nada cambia desde el punto de vista fenomenológico. Lo dado es para la conciencia exactamente igual, exista el objeto representado, o sea fingido o incluso contrasentido. No nos representamos a Júpiter de otro modo que a Bismarck, ni la torre de Babel de otro modo que la catedral de Colonia, ni un polígono regular de mil lados de otro modo que un poliedro regular de mil caras [...]. Teniendo en cuenta la impropiedad que hay en la expresión "estar contenido" intencionalmente el objeto en el acto, es innegable que las expresiones paralelas y equivalentes (el objeto es consciente, está en la conciencia, es inmanente a la conciencia, etc.) padecen de un equívoco muy nocivo» (Husserl, E. Investigaciones lógicas II. Madrid: Alianza, 1985, pp.: 495-496; cfr. también pp.: 529-530). También, muy importante, Husserl, E. Ideas relativas a una filosofía pura y una filosofía fenomenológica, Vol. I (nueva ed. de A. Zirión). México: UNAM y FCE, 2013, p.: 128 [§ 23]). 
que son sin duda creaciones de la imaginación, pero que en lo que respecta a la originalidad de las reconfiguraciones, a la abundancia de los rasgos singulares, a la continuidad de la motivación, exceden con mucho a las operaciones de nuestra propia fantasía, y a la vez y gracias a la fuerza sugestiva de los medios de expresión artística se traducen con particular facilidad en fantasías perfectamente claras al aprehenderlas en la comprensión. Así se puede decir realmente, si se ama el lenguaje paradójico, y decir con estricta verdad, con tal de que se entienda bien el equívoco sentido, que la "ficción" constituye el elemento vital de la fenomenología, como de toda ciencia eidética; que la ficción es la fuente de donde saca su sustento el conocimiento de las "verdades eternas" ${ }^{34}$.

Mas adelante, en el $\S 79$, dice Husserl que la ficcionalidad puede brindar a la fenomenología, que es equiparada a la geometría, incluso mejores intuiciones que los datos perceptivos ${ }^{35}$.

Sin embargo, con la Neutralitätsmodifikation Husserl da un paso decisivo adelante y quizás a una zona profunda y extrema de la vida de la conciencia, requiriéndose para penetrar en ella de un crucial giro de actitud. Ciertamente, en la zona de Neutralidad ya no se trata-Husserl lo advierte con claridad—de la ficción, sino justamente de una despedida provisional y táctica de la diferencia misma entre ficción y realidad y de su dialéctica, para intentar situarse en la protozona o zona previa a la escisión entre real/irreal, allí donde la conciencia y el campo de fenomenalidad precisamente se ofrecen en su pureza. Un campo de donación fenomenológica en el que la conciencia pudiera desenvolverse a sus anchas en sus potencialidades, liberada de compromisos; donde se pudiera "aprender" de todo sin saber, o mejor, sin preocuparse de saber si es real o irreal ni recibir presiones de género en tal sentido. Al pensar esta zona de neutralidad respecto a lo real o lo irreal, lo real o lo ficticio, la Fenomenología, indirectamente, pero habiéndolo presentido desde el comienzo, apoyaba otras decisiones contemporáneas en torno a lo Neutro de las que no podría ocuparme aquí. Se trata de una zona libérrima: la que siempre había deseado la praxis ficcional y el arte $^{36}$. En ese espacio podría aparecer este teclado en el que escribo pero también mi recuerdo del pasado verano, el Empire State Building de New York, la imagen de una hormiga transportando esforzadamente un grano, una sirena en la playa, el Cadeau de Man Ray, un lienzo de Gordillo, o uno de Zurbarán, o Monogram de Rauschenberg, o un pasaje de Molloy, de Beckett, o de Guerra y paz, de Tolstoi. Utopía plena, no por lo imposible (según la terminología de Baumgarten), sino por su Des-limitación absoluta. Apeiron radical el de esta zona de neutralidad, porque aunque lo que se da se diese según sus límites (esto o aquello, un zapato de cristal o una rana, un dragón o un ciempiés), la liberación de la escisión lo deja absolutamente todo en libertad, poniéndonos

${ }^{34}$ Husserl, E. Ideas I, pp.: 234-235 [§ 70].

${ }^{35}$ Ibid., p.: 261 [§ 79].

$36 \mathrm{Cfr}$. nuestra nota 50. 
a las puertas de aquel Todo brindado a la Intuición de que se habla en el Principio de todos los Principios husserliano: «No hay teoría concebible capaz de hacernos errar en cuanto al Principio de todos los principios: que toda intuición originariamente dadora es una fuente legitima de conocimiento; que todo lo que se nos ofrece en la "intuición" originariamente [...] hay que aceptarlo como lo que se $d a$, pero también sólo en los límites en que en ella se da» ${ }^{37}$. Utopía, así pues, de una fenomenalidad pura, irrestricta y realmente "sin complejos"... y no habría que decir "sin realidad", porque no cabe duda de que en esa zona también deberían poder aparecer y estar-dados fenómenos a los que pudiésemos llamar "reales"... Pero, si se me permite, reales sin Percepción-de-realidad (lo que la actitud natural entiende por tal); alucinatorios sin alucinaciones ${ }^{38}$, ficcionales sin ficciones. Husserl sabía que se trataba de un terreno inexplorado, que tampoco él, urgido como siempre se encontraba por requerimientos sistemático-programáticos, exploró suficientemente por lo que se refiere a los desafíos fenomenológicos de algunos pobladores libérrimos de esa zona ${ }^{39}$.

Sobre la modificación de neutralidad habla especialmente Husserl en los $\S$ 109-111 de Ideen I. En el primero de ellos, sobre la modificación de neutralidad [Die Neutralitätsmodifikation] Husserl se refiere a «una modificación que en cierto modo anula [aufhebt] por completo, quita por completo su fuerza [entkräftet] a toda modalidad dóxica a la cual se refiera» ${ }^{40}$, distinguiéndola de la negación, que al negar al mismo tiempo afirma, cuando pone lo negado. La modificación de neutralidad no pone, no afirma, no niega, no "obra" [leistet] nada. Para explicarlo, Husserl utiliza una batería de sinónimos de la epojé, porque en gran medida la modificación de neutralidad supone una suerte de culminación de la epojé. En efecto, se refiere Husserl al abstenerse-de-obrar [sich-desleistens-enthalten], poner-fuera-de-acción [es-ausser-Aktion-setzen], "colocarentre-paréntesis" [es-"einklammern"], "dejar-indeciso" [dabingestellt-sein-lassen], tener-"indeciso" ["dabingestellt"-haben],"ponerse a pensar"-en-el-obrar [sich-indas-leisten-"bineindenken"] o "meramente pensar" [bloss denken] en la obra, sin "tomar parte" [ohne "mitzutun"] ${ }^{41}$. Tras recordar que esta modificación nunca ha sido científicamente explorada, señala que ni siquiera se trataría de un hacer voluntario ${ }^{42}$. Sólo habría que quedarse con el resultado de este hacer (lo que en

${ }^{37}$ Husserl, E., Ideas I, p.: 129 [§ 24].

38 Ibid., pp.: 295-296 [§ 88].

${ }^{39}$ De esta cuestión me ocupo en El infinito fenomenológico, que espero vea la luz en un periodo razonable de tiempo. El hilo conductor que sigo (pero sin desarrollarlo pormenorizadamente) es el de la pregunta, a modo de apertura a un futurible, sobre qué habría ocurrido en el campo de la Fenomenología si hubiera llegado a producirse un encuentro con la vanguardia, habida cuenta de que la vanguardia y la mayor parte de los desarrollos de la Fenomenología de Husserl fueron contemporáneos.

${ }^{40}$ Husserl, E., Ideas I, p.: 343 [§ 109].

${ }^{41}$ Ibid., p.: 343 [§ 109].

42 Idem. 
este texto hemos nombrado como una ficción sin ficcionalización ${ }^{43}$ ). ¿Qué resta, pues? A juicio de Husserl, queda

«un tener-"estando ahí" algo que no es consciente "realmente" como estando ahí. El carácter de posición ha perdido su fuerza. La creencia ya no es en serio una creencia, el conjeturar no es en serio conjeturar, el negar no es en serio negar, etc. Es creer, conjeturar, negar, etc., "neutralizado", cuyos correlatos repiten los de las vivencias no-modificadas, pero de manera radicalmente modificada: lo que pura y simplemente es, lo que posible, probable, cuestionablemente es, e igualmente lo que no-es y todo lo demás que pueda decirse negado y afirmado, está conscientemente ahí, pero no a la manera de lo "real", sino como "meramente pensado", como "mero pensamiento". Todo tiene los "paréntesis" modificadores, emparentados con aquellos de los que antes tanto hablamos y que son tan importantes para abrir el camino a la fenomenología. Las posiciones puras y simples, las posiciones no-neutralizadas, tienen como correlatos resultantes "proposiciones", todas las cuales se caracterizan como algo "que es". La posibilidad, la probabilidad, la cuestionabilidad, el no-ser y el sí-ser, todo esto es ello mismo algo "que es": es decir, está caracterizado como tal en el correlato, "mentado" como tal en la conciencia. Pero las posiciones neutralizadas se distinguen esencialmente porque sus correlatos no contienen nada susceptible de ser puesto, nada realmente predicable; la conciencia neutral no desempeña en ningún respecto ante aquello de que es conciencia el papel de un "creer"»"${ }^{44}$.

En el $§ 110$ («Conciencia neutralizada y jurisdicción de la razón. El asumir») sostiene Husserl algo muy relevante, a fin de destacar «una incomparable peculiaridad de la conciencia». A saber, que

«las nóesis propias, no-neutralizadas, están por su esencia sujetas a una "jurisdicción de la razón", mientras que para las neutralizadas no tiene sentido alguno la cuestión de la razón y la sinrazón.

Lo mismo pasa, correlativamente, con los noémas. Todo lo caracterizado noemáticamente como existente (cierto), como posible, conjeturable, cuestionable, nulo, etc., puede estar caracterizado así en forma "válida" o "inválida", puede ser, ser posible, ser nulo, etc., "en verdad". En cambio, el mero imaginarse no "pone" nada, no es una conciencia posicional. El "mero pensamiento" de realidades, posibilidades, etc., no pretende nada; no cabe ni reconocerlo como correcto, ni rechazarlo por incorrecto» ${ }^{45}$.

${ }^{43}$ En este caso no es difícil, o respecto a la relación entre lo recordado y el recordar, pero en otros sería más complicado, como por ejemplo, por lo que se refiere a la posibilidad de separar lo visto del acto de ver. Por eso Husserl hablará luego de la Imagen.

${ }^{44}$ Husserl, E. Ideas I, p.: 343-344..

45 Ibid., p. 344. 
La modificación de neutralidad no equivale a un "suponer", que es un modo de "poner" sometible a una valoración racional. Finalmente, en el § 111, sobre «modificación de neutralidad y fantasía», Husserl busca distinguir entre ambas, lo que no es fácil habida cuenta de que, como mostrábamos antes, la fantasía ya supone un modificar neutralizante de la posición de realidad (modificar que podría aplicarse a todas las vivencias) o, como dirá Husserl, del recuerdo ${ }^{46}$. En lo que sigue, Husserl elegirá como ejemplo el conocido cuadro de Durero El caballero, la Muerte y el Diablo a fin de utilizar justamente la modificación de neutralidad para intentar penetrar no en la imagen en el lienzo, ni en la imagenreferente, sino en la imagen como imagen. Por más que es altamente relevante el análisis husserliano, no podríamos entretenernos con él ${ }^{47}$.

Lo que se da en la modificación de neutralidad no es propiamente ficcional, pero equivale a todo lo que la ficción podría brindar, incluyendo lo real, antes de la escisión entre realidad e irrealidad, o mejor- a fin de entendernos-antes de la obsesiva preocupación, tan propia de la actitud natural, por lo real o lo irreal. Por eso, para acceder a esta zona primero ha habido que pasar por la consideración de la neutralidad existencial de los objetos intencionales. Sin duda, la Modifikation beneficia más a la ficción que a la percepción de lo real, en la medida en que pone a aquélla en el mismo nivel que ésta. Avala todo aquello a lo que la ficción fuese capaz de acceder. De este modo le recompensa por los servicios prestados. La Gran Zona indiferente, neutral, al acreditar tanto ficciones como realidades, libera a todo lo ficcional de ser meramente ficcional, aportando a lo ficticio un ser por sí que ya no depende del proceso ficcional que lo ha propuesto. Y las meras realidades tampoco serán meras realidades, porque la neutralidad brinda a los contenidos de lo real un prestigio que los vislumbraría antes de ser fruto de cualquier recorte o selección. Si a la ficción se le dijese que va a dejar de ser mera-ficción, ingresando en la Zona neutral, cabe imaginar que no le importaría apenas. Por el contrario, semejante notificación a la percepción de lo real, a la que también podría complacerle, sin embargo, es más que razonable pensar que le inquietaría mucho (que se le diga que va a dejar de ser realidad), porque significaría restarle ese prestigio que posee por ser real, o recordarle su insuficiencia.

¿Sería, entonces, a un totum revolutum a lo que daría luz verde la modificación de neutralidad? ¿ No se trataría más bien del Proto-Aparecer? En él las lágrimas se mezclan con el humor, lo serio con lo divertido, lo real con lo irreal. En la modificación de actitud que reclama, la Neutralitätsmodifikation representa una posibilidad eminentemente filosófica, pues continuamente parecemos estar condicionados o inhibidos por la diferencia entre real e irreal. Puede parecer un esfuerzo casi sobrehumano (iprescindir de esa diferencia crucial!) pero en

46 Ibid., p.: 346 [§ 111].

${ }^{47}$ Ibid., pp. 347-349 [§ 111]. Cfr. nuestra nota 20. 
cierto modo efectuamos ese cambio de actitud ¡cada vez que entramos en el arte literario, poético, pictórico! En 1907, en una carta dirigida a Hugo von Hofmannsthal, Husserl se congratulaba de las coincidencias entre el arte y la fenomenología, diciendo del método fenomenológico que justamente pone entre paréntesis esa obsesión por la existencia que es propia de la actitud natural. Por eso:

«La intuición de una obra de arte puramente estética se ejecuta en estricta puesta entre paréntesis de cualquier actitud existencial del intelecto y de cualquier actitud del sentimiento y de la voluntad que como tal presuponga una actitud existencial. $\mathrm{O}$ mejor: la obra de arte nos traslada (a la vez que nos obliga) al estado de la intuición puramente estética que excluye aquella actitud [existencial]. Cuanto más es convocada o vitalmente atraída por el mundo existencial, cuanto más es reclamada la obra de arte a partir de sí por la actitud existencial (por ejemplo como apariencia de ser naturalística: verdad natural de la fotografia), menos puramente estética es la obra [...]. La actitud espiritual natural, la de la vida actual, es enteramente existencial. Las cosas que están sensiblemente ante nosotros, las cosas de que habla el discurso actual y científico, las ponemos como realidades y sobre estas posiciones de existencia se fundan actos de sentimiento y voluntad: alegría-de que esto sea—, tristeza - de que aquello no sea —, deseo-de que ello pudiera ser-, etc. (= posiciones existenciales del sentimiento): el contrapolo frente a la actitud espiritual de la intuición puramente estética y de la situación de sentimiento que le corresponde. Pero no menos el contrapolo frente a la actitud espiritual puramente fenomenológica, la única en que pueden ser solucionados los problemas filosóficos. Pues también el método fenomenológico reclama la estricta desconexión de todas las posiciones existenciales. Ante todo en la crítica del conocimiento.

Tan pronto como la Esfinge del conocimiento ha planteado su pregunta y hemos mirado en el profundamente abismático problema de la posibilidad de un conocimiento que, sin embargo, sólo se ejecuta en vivencias subjetivas y comprende a la vez una objetividad existente en sí, sólo entonces se ha transformado radicalmente nuestra actitud hacia todo conocimiento y ser predados-hacia toda ciencia y toda realidad pretendida. Todo cuestionado, todo incomprensible, jenigmático! El enigma sólo es solucionable si nos situamos sobre su suelo, si tratamos todo conocimiento como cuestionable y con ello no aceptamos ninguna existencia como predada. Con ello se tornan toda ciencia y toda realidad (también la del propio yo) mero "fenómeno" [...]. El artista que "observa" el mundo [...] se comporta respecto al mundo de forma parecida a como lo hace el fenomenólogo. Por tanto: no como observador investigador de la Naturaleza y psicólogo, no como práctico observador del hombre, como si pretendiese informaciones. Para él, en tanto reflexiona sobre el Mundo, éste se torna fenómeno, su existencia le es indiferente, precisamente como al filósofo (en la crítica de la razón). Sólo que él no tiende, como el 
filósofo, a fundamentar y aprehender en conceptos el "sentido" del fenómeno del mundo, sino a apropiárselo intuitivamente para abarcar así la plenitud de las configuraciones, materiales para configuraciones creativas estéticas» ${ }^{48}$.

$* * *$

De entre las muchas conclusiones que cabría extraer de la relevancia de la modificación de neutralidad, dos de las más interesantes serían: a) la enorme y libérrima amplitud de la experiencia que brinda, verdadera Plétora no sometida a los criterios que impondría o "sugeriría" todo aquello que exige resolver la pregunta sobre "¿real o irreal?", una pregunta ésta que no es importante para muchos ámbitos experienciales y de inteligibilidad; $y$ b) la radical profundidad y relevancia que, una vez practicada la epojé de la cuestión acerca de lo real e irreal, se le concede a lo neutro.

Por lo que se refiere a (a), y para ser breve, pienso en lo que dice Milan Kundera al comienzo de Los testamentos traicionados. El texto es un poco extenso pero, como en otras ocasiones, creo que merece la pena. Dice Kundera que:

«Madame Grandgousier, que estaba preñada, se dio tal hartazgo de callos que hubo que administrarle un astringente; éste fue tan fuerte que los lóbulos de la placenta se aflojaron, el feto de Gargantúa se deslizó dentro de una vena, subió por ella y salió por la oreja de su madre. Desde las primeras frases, el libro descubre sus cartas: lo que aquí se cuenta no es serio: lo cual significa: aquí no se afirman verdades (científicas o míticas); nadie se compromete a dar una descripción de los hechos tal como son en realidad.

Hermosos tiempos los de Rabelais: la novela alza el vuelo llevándose en su cuerpo, cual mariposa, los jirones de la crisálida. [...] El momento excepcional del nacimiento de un arte nuevo otorga al libro de Rabelais una inaudita riqueza; todo está ahí: lo verosímil y lo inverosímil, la alegoría, la sátira, los gigantes y los hombres normales, las anécdotas, las meditaciones, los viajes reales y fantásticos, los debates eruditos, las digresiones de puro virtuosismo verbal. El novelista de hoy, heredero del siglo XIX, siente una envidiosa nostalgia de ese universo soberbiamente heteróclito de los primeros novelistas y de la alegre libertad con la que lo habitan. Del mismo modo que Rabelais en las primeras páginas de su libro deja caer a Gargantúa en el escenario del mundo por la oreja de su madre, en Los versos satánicos, tras la explosión de un avión en pleno vuelo, los dos protagonistas de Salman Rushdie caen conversando y cantando, y se comportan de una manera cómica e improbable [...]. La novela arranca con esta escena, ya que Rushdie, al igual que Rabelais, sabe que el contrato entre el novelista y el lector debe establecerse desde el principio; eso debe quedar claro: lo que aquí se cuenta no va en serio aunque se trate de cosas muy terribles. La comunión de lo no serio con lo terrible: he

48 Husserl, E. Brief an H. Von Hofmannsthal, en Husserliana III, Briefwechsel, Teil 7, Dordrecht: Springer, 1994, pp.: 133-135 (cit. en Moreno, C. Fenomenología y filosofía existencial I. Madrid: Síntesis, 2000, pp.: 62-64). 
aquí una escena del Libro Cuarto: la nave de Pantagruel encuentra en alta mar un barco lleno de comerciantes de corderos; un comerciante, al ver a Panurgo desbraguetado, con los lentes encima del gorro, se cree autorizado a dárselas de listo y le trata de cornudo. Panurgo se venga enseguida: le compra un cordero y luego lo tira al mar; siendo propio de los corderos seguir al primero, todos los demás empiezan a tirarse al agua. Enloquecidos, los comerciantes los agarran por la lana y los cuernos y son ellos también arrastrados al mar. Panurgo tiene un remo en la mano, no para salvarlos, sino para impedir que suban a bordo; los exhorta con elocuencia, demostrándoles las miserias de este mundo, el bien y la dicha de la otra vida, y afirmando que los difuntos son más felices que los vivos. [...] Esta escena es irreal, imposible; ¿`se desprende al menos de ella alguna moral? ¿Denuncia Rabelais la mezquindad de los comerciantes cuyo castigo debería alegrarnos, o quiere que nos indignemos contra la crueldad de Panurgo, o se burla, como buen anticlerical que es, de la necedad de los estereotipos religiosos que profiere Panurgo? ¡Adivinen! Cada respuesta es una trampa para tontos. Escribe Octavio Paz: "Ni Homero ni Virgilio conocieron el humor; Ariosto parece presentirlo, pero el humor no toma forma hasta Cervantes. [...] El humor es la gran invención del espíritu moderno". Idea fundamental: el humor no es una práctica inmemorial del hombre; es una invención unida al nacimiento de la novela. El humor, pues, no es la risa, la burla, la sátira, sino un aspecto particular de lo cómico, del que dice Paz (y ésta es la clave para comprender la esencia del humor) que "convierte en ambiguo todo lo que toca". Los que no saben disfrutar de la escena en la que Panurgo deja ahogarse a los comerciantes de corderos mientras les hace el elogio de la otra vida nunca comprenderán nada del arte de la novela» ${ }^{49}$.

Cuando nos situamos en la zona de la modificación de neutralidad somos convocados por, y debemos responder a (hacernos responsables de) aquello que se da en tanto se da, precisamente antes de, o después de o independiente de preguntar/decidir acerca de su realidad o irrealidad. Aparecerían no sólo "definiciones"-de un centauro, de un cinturón, de un abeto, de una raíz cuadrada-, sino experiencias y acontecimientos... incluso Marbot o Jimmy o la fotografía Muerte de un miliciano, o el relato radiofónico de La guerra de los mundos de Orson Welles... Por otra parte, cabe también considerar que en esa zona somos convocados experiencialmente, aunque no sea real ni irrealmente. Respecto a la cuestión que plantea la escena del envenenamiento en El asesinato de Gonzago que Hamlet manipula (me referí a ello anteriormente), lo cierto es que en la escena no se envenena de verdad ni en broma: se envenena, simplemente. Las perspectivas acerca de la cuestión se contrarrestan y anulan entre sí, para dejar finalmente sólo el "envenenamiento" y su cualificación. Como decía Derrida del

${ }^{49}$ Kundera, M. Los testamentos traicionados. Barcelona: Círculo de Lectores, 1994, pp. 11-14. 
noema ${ }^{50}$, cabría hablar de la anarquía de la zona de modificación de neutralidad, ni real ni irreal, ni psíquica. Respecto al envenenamiento, todo depende de en qué terreno se sitúe cada uno. Si uno se sitúa fuera de la escena y del patio de butacas, es cierto que envenenan en broma. Pero si uno se sitúa dentro de la escena, envenenan realmente. ¿Y la conclusión? En la zona abierta y acotada por la modificación de neutralidad, habrá que aproximarse a la experiencia misma del envenenamiento (¿real? ¿irreal?... ¿ ¿no sigue siendo, en cualquier caso, un envenenamiento?). Esta cuestión nos haría avanzar hacia terrenos en los que el trato con, por ejemplo, realidades ficcionales/virtuales cobra su importancia. En muchas ocasiones asistimos a debates sobre productos culturales en principio ficcionales, pero que por su contenido resultan un tanto, digamos, alarmantes, a lo que suele replicarse aduciendo que son "meramente ficcionales", y que no implican el tránsito a lo real... como si todo lo decisivo se jugase en ese posible tránsito. Sin embargo, nuestra conciencia se desenvuelve con especial soltura y diría que plasticidad justamente sin tener que decidir acerca de lo real o lo irreal, y en tal ámbito, el modo en que queda involucrada o comprometida la subjetividad o la conciencia no es irrelevante.

\section{EPÍLOGO EXISTENCIAL. LAS VIDAS POSIBLES}

Baste una brevísima nota final, de marcado carácter existencial. La diferencia entre lo real y lo irreal se da con especial agudeza en la medida en que en ella se juega no la vida de un tal "Marbot" o la de un tal "Jimmy", sino nuestra vida... y añadiremos de inmediato: nuestra vida de veras, ¡más que nuestra vida real! En el fondo, quizás sea de esta diferencia de donde surgen las restantes, que pasarían a ser subsidiarias. Pero, ¿podríamos prescindir de la cuestión de lo real y lo irreal respecto a nuestra vida? Aunque no podríamos vivir de hecho nuestra vida prescindiendo de esa diferencia, ¿no hay una dimensión de nuestra vida, en la que la vida de hecho queda como sobrepasada por una verdad-de-nuestravida más desmesurada y quizás poderosa, más irrestricta por no haber estado sometida a los designios de lo real? José Ortega y Gasset dejó escrito:

«Cuando un día escriba mis Memorias procuraré hacerlo según creo que es debido. Las Memorias o su sustituto la novela en que contamos nuestra vida, se proponen, en definitiva, salvar ésta, evitar su absoluta volatilización. Quisiéramos, agradecidos, devolver a la vida lo que ella nos ha dado, o le hemos arrancado, devolverlo después de meditarlo y alquitararlo [...] Pues bien, no me parece justo que salvemos sólo la vida que de hecho hemos vivido. Todos tenemos la conciencia de que conforme nos íbamos realizando en la existencia caían a diestra y siniestra, decimadas por el destino, otras vidas que igualmente podríamos haber vivido. La fatalidad ha seleccionado de nuestras

${ }^{50}$ Derrida, J. “Génesis y estructura' y la fenomenología”. En La escritura y la diferencia. Barcelona: Anthropos, 1989, p.: 224. 
posibles trayectorias una y ha eliminado las demás. Mis Memorias contarán también, junto a mi vida efectiva, las que pude vivir, vidas desnucadas antes de nacer, pobres existencias que para siempre quedaron exangües sin ser cumplidas, espectros errabundos que son nuestro múltiple ser fracasado. No se trata de abstractas posibilidades, sino que cada ser humano lleva en torno al núcleo de su existencia efectiva un elenco concreto, individualísimo de otras posibles vidas, suyas y no sólo suyas. Y solamente destacándolo sobre el fondo de esas biografías espectrales aparece claro y rigoroso el perfil fatal, estricto de nuestro destino» ${ }^{51}$.

Que la experiencia en los órdenes y desórdenes ficcionales haya contribuido a este esclarecimiento existencial parece, a estas alturas, indudable, habiéndose ubicado nuestra verdad, más que nuestra realidad, en un terreno cruzado por nuestras realidades, ciertamente-quién podría cuestionarlo-, pero también por nuestras verdades irreales.

\section{BIBLIOGRAFÍA}

Albaladejo, T. 1992. Semántica de la narración: la ficción realista. Madrid: Taurus.

Barthes, R. 1970. "El efecto de realidad". En AA.VV. Lo verosimil, Buenos Aires: Tiempo Contemporáneo, 95-101.

Baumgarten, A. G. 1964. Reflexiones filosóficas acerca de la poesía. Madrid: Aguilar.

Blanchot, M. 1992. El libro que vendrá. Caracas: Monte Ávila Editores.

Blanchot, M. 1970. El diálogo inconcluso. Caracas: Monte Ávila Editores.

BRECHT, B. 2010. Escritos sobre teatro. Barcelona: Alba editorial.

Breton, A. 1924. "Primer manifiesto del surrealismo". En Manifiestos del surrealismo, Barcelona: Labor, 1992.

Derrida, J. 1989. “Génesis y estructura' y la fenomenología”. En La escritura y la diferencia. Barcelona: Anthropos.

СоокE, J. 1980. “Jimmy's world". Extraído de la la web http://www2.uncp.edu/home/ canada/work/markport/lit/litjour/spg2002/cooke.htm

García Márquez, G. 1981. “¿Quién cree a Janet Cooke”. Extraído de ”http://elpais. com/diario/1981/04/29/opinion/357343203_850215.html

Geertz, C. 1989. La interpretación de las culturas. Barcelona: Gedisa.

Hildesheimer, W. 1984. Marbot. Eine Biographie. Frankfurt: Suhrkamp.

Husserl, E. Investigaciones lógicas II. Madrid: Alianza, 1985.

Husserl, E. Ideas relativas a una filosofía pura y una filosofía fenomenológica, Vol. I (nueva ed. de A. Zirión). México: UNAM y FCE, 2013.

Husserl, E. 1994. Brief an H. Von Hofmannsthal, en Husserliana III, Briefwechsel, Teil 7, Dordrecht: Springer, pp.: 133-135 (cit. en Moreno, C., Fenomenología y filosofía existencial I. Madrid: Síntesis, 2000, pp.: 62-64).

Kundera, M. 1987. El arte la novela. Barcelona: Tusquets.

51 Ortega y Gasset, J. “Intimidades”. En El espectador VII, Obras completas II. Madrid: Taurus/ Revista de Occidente, 2004, pp.: 729-730. 
Kundera, M. 1994. Los testamentos traicionados. Barcelona: Círculo de Lectores.

Leibniz, G.W. "Sobre el modo de distinguir los fenómenos reales de los imaginarios". En Escritos filosóficos (E. DE Olaso, ed.). Buenos Aires: Charcas, 1982, pp.: 265-270.

Lotman, Y. 1982. Estructura del texto artístico. Barcelona: Itsmo.

Macón, C. y Tozzi, V. 2005. "El acontecimiento extremo: experiencia traumática y disrupción de la representación histórica”. En LA COMPRENSIón DEL PASADO. Escritos sobre filosofía de la historia (M. Cruz y D. Brauer, comps.). Barcelona, Herder, 111-132.

Marías, J. 1994. "Ficciones bastardas". El País Semanal, 4 de diciembre de 1994: 8.

Moreno, C. 1991. "Filosofía primera y texto mínimo. Reducción fenomenológica y acto de leer”. En Radicalidad y Episteme (J. Villalobos, ed.), Sevilla: Universidad de Sevilla, 107-131.

Moreno, C. 2001. "Deseo de realidad. Un fragmento (autobiográfico) de mi Discurso del método". En AA.VV., Que piensen ellos, Madrid: Opera Prima, 127-140.

Moreno, C. 2005. "Dinámica de la intuición. Reflexiones sobre la donación fenomenológica y el fin del conocimiento en Husserl (con una incursión en el caso-Chandos)". En Signo, intencionalidad, verdad. Estudios de Fenomenología (César Moreno y Alicia De Mingo, eds.), Sevilla: Universidad de Sevilla, 57-70.

Moreno, C. 2013. "Neutralidad e infinito. Propedéutica fenomenológica sobre la Imagen y el Acontecimiento". Boletin de Estudios de Filosofía y Cultura Manuel Mindán 8: 41-71. Hay versión online.

Ortega y Gasset, J. “Intimidades". En El espectador VII, Obras completas II. Madrid: Taurus/Revista de Occidente, 2004, pp.: 728-755.

Pozuelo Yvancos, J. M. 1993. Poética de la ficción. Madrid: Síntesis.

Schaeffer, J.-M. 2002. ¿̇Por qué la ficción? Madrid: Lengua de trapo.

Shakespeare, W. Hamlet. En Hamlet/Macbeth. Barcelona: Planeta, 1980.

Vaininger, H. 1986. Die Philosophie des Als-Ob. Darmstadt: Scientia Verlag. 